\title{
Prevalence of alcohol, tobacco and street drugs consumption in adult Latin American immigrants
}

\author{
José Rafael González-López² \\ María de los Ángeles Rodríguez-Gázquez ${ }^{3}$ \\ María de las Mercedes Lomas-Campos ${ }^{4}$
}

To estimate the prevalence of alcohol, tobacco and illicit drug consumption (through the selfreport) in adult Latin-American immigrants of Seville, a cross-sectional descriptive study was carried out in a representative sample of 190 immigrants. The results showed that $61.4 \%$ of the participants had consumed alcohol in previous month before data collection, although $13.2 \%$ of them were at risk of alcoholism. Moreover, $30.0 \%$ were smokers. In addition, $5.3 \%$ of the interviewed people had consumed illicit psychoactive substances in the previous six months (Marihuana: $3.7 \%$, hashish: $1.1 \%$ and cocaine: $0.5 \%$ ). For all substances under analysis, the consumption prevalence was much higher in men from 25 to 39 years of age. In conclusion, prevalence levels of this consumption were high among the studied immigrants. Nurses could train the population in the prevention of these risk behaviors through preventive practices.

Descriptors: Emigration and Immigration; Prevalence; Alcohol Drinking; Tobacco; Street Drugs; Latin America.

\footnotetext{
${ }^{1}$ This research was supported by Consejería de Salud de la Junta de Andalucía (PI-0138), Spain.

2 PhD, Professor, Facultad de Enfermería, Fisioterapia y Podología, Universidad de Sevilla, Spain.

${ }^{3}$ PhD, Associate Professor, Facultad de Enfermería, Universidad de Antioquia, Colombia.

${ }^{4}$ PhD, Full Professor, Facultad de Enfermería, Fisioterapia y Podología, Universidad de Sevilla, Spain.
} 


\section{Prevalência do consumo de álcool, tabaco e drogas ilícitas em adultos imigrantes latino-americanos}

Para estimar a prevalência de autorrelato de consumo de álcool, tabaco e drogas ilícitas da população adulta de latino-americanos imigrantes, de Sevilha, foi realizado estudo transversal descritivo em amostra representativa com 190 imigrantes. Os resultados mostraram que $61,4 \%$ dos sujeitos ingeriam bebidas alcoólicas no mês anterior à coleta de dados, 13,2\% dos participantes apresentaram risco para alcoolismo, 30,0\% já eram fumantes, 5,3\% dos entrevistados nos últimos seis meses haviam consumido drogas ilícitas (maconha: $3,7 \%$, haxixe: $1,1 \%$ e cocaína: 0,5\%). Para todas as substâncias investigadas, a prevalência do consumo foi maior em homens com idade entre 25 e 39 anos. Conclui-se que os imigrantes apresentaram alta prevalência de consumo de drogas. A enfermeira pode atuar na prevenção desses comportamentos de risco por meio da execução de práticas educativas.

Descritores: Migração Internacional; Prevalência; Consumo de Bebidas Alcoólicas; Tabaco; Drogas Ilícitas; América Latina.

\section{Prevalencia de consumo de alcohol, tabaco y drogas ilícitas en inmigrantes latinoamericanos adultos}

Con el fin de estimar la prevalencia por autorreporte del consumo de alcohol, tabaco y drogas ilícitas en la población adulta de inmigrantes latinoamericanos en Sevilla, se realizó un estudio descriptivo de corte transversal en una muestra representativa de 190 inmigrantes. Los resultados mostraron que el $61,4 \%$ de los sujetos bebió alcohol en el mes anterior a la recolección de datos, y el $13,2 \%$ de los participantes mostró tener riesgo de alcoholismo. El $30,0 \%$ ya era fumador. El 5,3\% de los encuestados ha consumido drogas ilícitas en los últimos seis meses (marihuana: 3,7\%, el hachís, la cocaína un 1,1\% y 0,5\%). Para todas las sustancias investigadas, la prevalencia de consumo fue mayor en hombres de 25-39 años. Se concluye que los inmigrantes tienen una alta prevalencia de consumo de drogas. La enfermera puede prevenir estos comportamientos de riesgo mediante la implementación de prácticas educativas.

Descriptores: Migración Internacional; Prevalencia; Consumo de Bebidas Alcohólicas; Tabaco; Drogas Ilícitas; América Latina.

\section{Introduction}

In the 1970's, in the Lalonde report, the need was emphasized to evolve from mere care interventions, and that governments should also be concerned with intervening in the risk factors of their populations' lifestyles, which was further expressed in the 1986 Ottawa Charter. The IV International Conference on Health Promotion, celebrated in Jakarta in 1997, further elaborated on the need to enhance awareness of these lifestyles, especially among the poorest. In principle, fundamentally due to the living and work conditions they are frequently submitted to, immigrants fit into this category in comparison with the autochthonous population in the receiving zones.
Immigrants bring different types of behavior and perceptions about access to social health services and drugs consumption $^{(1)}$. Also, the migration process produces new situations related to substance $u^{(2)}$. Migration entails social stress (post-migration stress), with social, health and economic implications that are often accompanied by a loss of family structure, representing an important risk factor for drugs consumption. Alcohol and tobacco are risk factors, causing 12 percent of deaths around the world, according to a World Health Organization study(3). Although tobacco is the major preventable cause of death in the world(4), its consumption is a growing epidemic and, unless urgent action is taken, the number of smokers will continue increasing. 
Different studies ${ }^{(5-6)}$ on lifestyles and health determinants have looked at tobacco, alcohol and drugs consumption. Results demonstrate distinguished habits between the autochthonous and foreign populations, particularly a higher prevalence of harmful determinants of health. Data from the Spanish National Survey on Drugs Use and Health (NSDUH) indicate distinctly different lifetime consumption rates for illegal substances (cocaine, marihuana and hashish) between Latin and non-Latin white people (37.2\% vs. $48.1 \%$, respectively) ${ }^{(7)}$. In España, one study(8) found a specific social problem concerning adult immigration and drugs consumption. High current alcohol (93.9\%) and tobacco (63.9\%) consumption levels appear in the study population(5), concretely among Ecuadorians in leisure contexts, while practicing sports in the company of friends and relatives. According to the Statistical Yearbook on Immigration ${ }^{(9)}$, in 2009, $8 \%$ of Latin American immigrants in Spain were in Andalucía. In Seville, this group represented almost half (46.3\%) of the immigrant population.

Health problems associated with the consumption of tobacco, alcohol and other drugs demand further attention from health services and adequate public intervention policies $^{(10)}$. Thus, Nursing is in an excellent position to play a prominent role in alcohol, tobacco and drugs consumption control: professionals have the opportunity to help the community change its unhealthy lifestyles and sensitize the immigrant group to resulting problems with a view to eradicating risk behaviors ${ }^{(11)}$. Cultural care is an interesting alternative for nursing practice and research in displaced and migrating populations. In her "Transcultural Nursing" theory, Leininger explains how different economic, religious, cultural, political factors, lifestyles, technological factors, ethnic history, religion (moral code), cultural values and generic practices influence health in a holistic perspective ${ }^{(12)}$. As the immigration phenomenon is relatively recent in Spain, few studies exist about the relation between drugs dependence and the immigrant population ${ }^{(5)}$.

\section{Aim}

To estimate the self-reported prevalence of alcohol, tobacco and drugs consumption in the adult Latin American population of Seville during 2011.

\section{Method}

A descriptive and cross-sectional study was developed, using stratified sampling with proportional allocation for gender, age and administrative district. From a total population of 8,675 immigrants, a representative sample of 190 adult Latin American immigrants between 25 and 44 years of age was taken; this age range was used because it is the most frequent in this population ${ }^{(9)}$

Some behavior-related sections were used from the Risk Factor Surveillance System (2009) from the US Centers for Disease Control and Prevention(13). In this paper, results will be presented for: a) participants' sociodemographic data (sex, age, marital status, education level, place of birth, time of stay in Spain and occupation), b) consumption of alcohol, tobacco and illicit drugs (marihuana, hashish, cocaine). The prevalence rates of tobacco, alcohol and drugs were calculated, dividing the number of people who affirmed this habit by the study participants.

For this research, immigrant refers to "that person whose country of origin is distinct from Spain and, at the time of this survey, has established habitual residency within the national territory", which corresponds to the definition the Spanish National Institute of Statistics used in its 2007 National Survey of Immigrants ${ }^{(14)}$.

Data were collected between January and May 2011. The selection criteria were: male or female person living in some of the Official Neighborhoods or Census Sectors in the 11 administrative districts of the city of Seville; age between 25 and 44 years; born in any of the countries the United Nations Organization recognizes in its list of nationalities, territories and regions(15) as Latin or South American countries (Argentina, Bolivia, Brazil, Chile, Colombia, Cuba, Ecuador, Paraguay, Peru, Uruguay, Venezuela) and having immigrated to Spain; able to communicate and understand the study requirements and having signed the informed consent term. A single surveyor collected the data.

To capture the participants, different Latin American immigrant associations and groups were contacted to facilitate data collection. The procedures used to accomplish this study complied with the ethical principles in the World Medical Association's 1975 Helsinki Declaration (updated version 2008); participants signed the informed consent term and, concerning sociodemographic data, to protect honor, anonymity and personal intimacy, according to Organic Law 15/1999 on the Protection of Personal Data, questionnaires were numbered.

Data were analyzed using SPSS version 17.0 for Windows statistical software. Descriptive analyses were applied, with central trend and dispersion measures for 
quantitative and proportions for qualitative variables. Relations between some variables of interest were explored, using statistics indicated for independent samples, as follows: a) difference of proportions: $\mathrm{X}^{2}$ was applied in case of expected values in contingency tables $\geq 5$; if not, Yatees' continuity correction was used; b) difference of means: Student's t-test was used; c) evaluation of strength of association: the Odds Ratios were calculated with their respective 95\% confidence intervals; and d) cluster analysis: to explore if the study group contained underlying natural clusters with similar characteristics.

\section{Results}

\section{Sociodemographic characteristics}

The general sociodemographic profile of the 190 participants was as follows: the mean age is $33.8 \pm 6.3$ years; $60 \%$ are women; as to marital status, married $(45.3 \%)$, single $(36.8 \%)$ and people living with a fixed partner (8.9\%) are predominant; regarding education, $3.7 \%$ have no degree, $15.3 \%$ have finished primary, $40.0 \%$ secondary, $16.8 \%$ higher education and the remaining $24.2 \%$ hold a university degree. Concerning the country of origin, in decreasing order of contribution: Bolivia (32.6\%), Peru (18.9\%), Colombia $(16.8 \%)$, Ecuador (11.1\%), Paraguay (5.2\%), Chile $(4.2 \%)$, Brazil (1.6\%), Nicaragua (1.1\%), and Argentina and Cuba ( $0.5 \%$ each). The analysis of the time of residence in Spain showed a mean $5.4 \pm 3.6$ years, slightly higher than the mean time of residence in Seville (4.6 \pm 3.2 years). As regards past occupation, the highest proportions are for employed (53.7\%), selfemployed $(13.3 \%)$, unemployed and student $(11.6 \%$ each) and housewife (5.8\%). The most frequent current occupation, on the other hand, was employed (59.3\%), followed by self-employed (18.4\%), unemployed $(10.5 \%)$, student $(6.8 \%)$ and housewife $(4.7 \%)$. A moderate correlation was found ( $r o=0.36 ; p<0.01)$ between previous and current occupation.

\section{Alcohol consumption}

In the last month, the prevalence of alcohol consumption was $61.4 \%\left(\mathrm{CI}_{95 \%}=47.4 \%-61.9 \%\right)$. According to Table 1 , prevalence levels in the last month were almost seven times higher than in women, a statistically significant finding. Although no differences were found per age or education level, the monthly prevalence of alcohol consumption was higher in the group from 25 to 34 years and among people who had finished primary education or less. People started drinking at the mean age of $16.6 \pm 5.3$ years.

As for the risk of alcoholism, measured through the CAGE instrument, $13.2 \%$ of participants $\left(\mathrm{CI}_{95 \%}=8.4 \%\right.$ $18.3 \%$ ) show some and $6.8 \%$ high risk. Statistically significant differences were found according to sex (higher risk in men) and age (higher in people between 25 and 34 years of age). (Table 1 )

\section{Smoking cigarettes}

Thirty percent $\left(\mathrm{CI}_{95 \%}=23.6 \%-37.1 \%\right)$ of the study participants have smoked during the lifetime. At the time of the survey, $26.3 \%$ were smokers, $3.7 \%$ former smokers and the remainder (70.0\%) nonsmokers. The median number of cigarettes current smokers consume per day was four, so that $95.6 \%$ of these people smoke less than a pack per day. In the last year, $10.5 \%$ of this group has intended to quit smoking. The mean age they started to smoke is $17.6 \pm 5.1$ years. No significant differences were found per age group, sex or education level.

\section{Illegal psychoactive substance consumption}

In the last six months, $5.3 \%$ of participants have consumed an illegal psychoactive substance $\left(\mathrm{CI}_{95 \%}=2.7 \%\right.$ 9.7\%). According to substance type, the highest prevalence was found for marihuana with 3,7\% $\left(\mathrm{CI}_{95 \%}=1.5 \%-7.4 \%\right)$, followed by hashish with $1.1 \%\left(\mathrm{CI}_{95 \%}=0.1 \%-3.8 \%\right)$ and cocaine with $0.5 \%\left(\mathrm{CI}_{95 \%}=0.0 \%-2.9 \%\right)$. Consumption of any other substance of this type was not reported. According to Table 1, no differences were found per sex or age group, as opposed to education, considering that the risk of having consumed these substances was almost five times higher among people with primary education or less when compared to the group with secondary and higher education.

Table 2 displays the clusters for alcohol consumption in the last month, with a male profile, between 25 and 29 years, self-employed, with higher education and time of stay in Seville two years and a half. This profile is very similar to that of toxic substance consumers in the last 6 months and that of risk of alcoholism. The difference for the former is a much longer time of stay in the city.

As this is a cluster analysis, some sample subjects did not fit into any group as they did not comply with all requisites for each cluster. 
Table 1 - Percentage prevalence of tobacco consumption in the lifetime, alcohol consumption in the last month and toxic substance consumption in the last six months among 190 Latin American immigrants living in Seville

\begin{tabular}{|c|c|c|c|c|c|}
\hline Alcohol consumption in the last month & $\mathbf{N}$ & Prevalence $61.4 \%$ & Statistics & p & $\mathrm{OR}\left(\mathrm{Cl}_{95 \%} \mathrm{OR}\right)$ \\
\hline \multicolumn{6}{|l|}{ Age group in years } \\
\hline $25-34$ & 101 & 59.4 & $1.8^{*}$ & 0.168 & $1.4(0.8-2.6)$ \\
\hline $35+$ & 89 & 49.4 & & & 1.0 \\
\hline \multicolumn{6}{|l|}{ Sex } \\
\hline Man & 76 & 80.3 & $33.3^{*}$ & $<0.001$ & $6.7(3.4-13.2)$ \\
\hline Woman & 114 & 37.7 & & & 1.0 \\
\hline \multicolumn{6}{|l|}{ Education } \\
\hline Primary and less & 38 & 58.3 & 0.2 & 0.630 & $1.2(0.6-2.4)$ \\
\hline Secondary and more & 152 & 53.7 & & & 1.0 \\
\hline Risk of alcoholism -CAGE- & $\mathbf{N}$ & Prevalence $13.2 \%$ & Statistics & $p$ & $\mathrm{OR}\left(\mathrm{Cl}_{95 \%} \mathrm{OR}\right)$ \\
\hline \multicolumn{6}{|l|}{ Age group in years } \\
\hline $25-34$ & 101 & 17.8 & $4.10^{*}$ & 0.043 & $2.54(1.1-6.4)$ \\
\hline $35+$ & 89 & 7.9 & & & 1.0 \\
\hline \multicolumn{6}{|l|}{ Sex } \\
\hline Man & 76 & 27.6 & $23.2^{*}$ & $<0.001$ & $10.5(3.4-32.1)$ \\
\hline Woman & 114 & 3.5 & & & 1.0 \\
\hline \multicolumn{6}{|l|}{ Education } \\
\hline Primary and less & 38 & 19.4 & $1.5^{\dagger}$ & 0.216 & $1.8(0.6-4.7)$ \\
\hline Secondary and more & 152 & 11.3 & & & 1.0 \\
\hline Smoking in the lifetime & $\mathbf{N}$ & Prevalence $\mathbf{3 0 . 0 \%}$ & Statistics & $p$ & OR (Cl $\left.{ }_{95 \%} \mathrm{OR}\right)$ \\
\hline \multicolumn{6}{|l|}{ Age group in years } \\
\hline $25-34$ & 101 & 29.7 & 0.07 & 0.924 & $0.9(0.5-1.8)$ \\
\hline $35+$ & 89 & 30.3 & & & 1.0 \\
\hline \multicolumn{6}{|l|}{ Sex } \\
\hline Man & 76 & 35.5 & $1.84^{*}$ & 0.175 & $1.5(0.8-2.9)$ \\
\hline Woman & 114 & 26.3 & & & 1.0 \\
\hline \multicolumn{6}{|l|}{ Education } \\
\hline Primary and less & 38 & 33.3 & $0.2^{*}$ & 0.628 & $1.2(0.5-2.6)$ \\
\hline Secondary and more & 152 & 29.2 & & & 1.0 \\
\hline Toxic substance consumption in the last 6 months & $\mathbf{N}$ & Prevalence $5.3 \%$ & Statistics & $\mathrm{p}$ & $\mathrm{OR}\left(\mathrm{Cl}_{95 \%} \mathrm{OR}\right)$ \\
\hline \multicolumn{6}{|l|}{ Age group in years } \\
\hline $25-34$ & 101 & 7.9 & $2.02^{\dagger}$ & 0.081 & $3.7(0.7-18.1)$ \\
\hline $35+$ & 89 & 2.2 & & & 1.0 \\
\hline \multicolumn{6}{|l|}{ Sex } \\
\hline Man & 76 & 7.9 & $1.7^{\dagger}$ & 0.186 & $2.3(0.6-8.6)$ \\
\hline Woman & 114 & 3.5 & & & 1.0 \\
\hline \multicolumn{6}{|l|}{ Education } \\
\hline Primary and less & 38 & 13.9 & $6.6^{\dagger}$ & 0.010 & $4.8(1.3-17.6)$ \\
\hline Secondary and more & 152 & 3.2 & & & 1.0 \\
\hline
\end{tabular}

*: Pearson's $\mathrm{X}^{2} ;{ }^{+}$: with Yates correction

\section{Discussion}

Some studies exist in Spain about immigrant health and the importance of sociodemographic, economic factors and lifestyles ${ }^{(16-17)}$. Nevertheless, except in two studies ${ }^{(5,8)}$ that found a specific social problem related to immigration and drugs consumption, there has been a lack of research about the prevalence of tobacco, alcohol and other drugs consumption once they reach their country of destination.
We do know, however, about the high prevalence of alcohol (44\%) and tobacco (26\%) consumptions in the Latin American countries of origin (Argentina, Bolivia, Chile, Colombia, Ecuador, Peru and Uruguay) through different studies ${ }^{(3,18)}$.

In this research, the consumption patterns in the adult Latin immigrant population in Seville are shown, observing high levels for alcohol (in the last month: $61.4 \%$ ) and tobacco consumption (in the lifetime: 
Table 2 - Clusters for alcohol consumption in the last month, risk of alcoholism, having smoked in life and having consumed toxic substances in the last 6 months

\begin{tabular}{|c|c|c|c|c|}
\hline \multirow[b]{2}{*}{ Variable } & \multicolumn{2}{|c|}{ Alcohol consumption in the last month } & \multicolumn{2}{|c|}{ Risk of alcoholism } \\
\hline & $\begin{array}{c}\text { Yes } \\
n=101\end{array}$ & $\begin{array}{c}\text { No } \\
n=85\end{array}$ & $\begin{array}{c}\text { Yes } \\
n=23\end{array}$ & $\begin{array}{c}\text { No } \\
n=119\end{array}$ \\
\hline Sex & Male & Female & Male & Female \\
\hline Age & 25 to 29 & 35 to 39 & 30 to 34 & 35 to 39 \\
\hline Previous occupation & Self-employed & Unemployed & Employed & Student \\
\hline Current occupation & Self-employed & Employed & Self-employed & Employed \\
\hline Education level & Higher & Higher & Secondary & Higher \\
\hline Mean time of stay in Spain & 3.5 & 4.0 & 4.1 & 20.0 \\
\hline Mean time of stay in Seville & 2.6 & 3.8 & 2.3 & 14.0 \\
\hline \multirow[b]{2}{*}{ Variable } & \multicolumn{2}{|c|}{ Smoking in life } & \multicolumn{2}{|c|}{ Toxic substance consumption in the last 6 months } \\
\hline & $\begin{array}{c}\text { Yes } \\
n=47\end{array}$ & $\begin{array}{c}\text { No } \\
n=84\end{array}$ & $\begin{array}{c}\text { Yes } \\
n=10\end{array}$ & $\begin{array}{c}\text { No } \\
n=176\end{array}$ \\
\hline Sex & Male & Female & Male & Female \\
\hline Age & 35 to 39 & 30 to 34 & 25 to 29 & 30 to 34 \\
\hline Previous occupation & Unemployed & Self-employed & Self-employed & Self-employed \\
\hline Current occupation & Self-employed & Self-employed & Self-employed & Self-employed \\
\hline Education level & Higher & Secondary & Primary & Higher \\
\hline Mean time of stay in Spain & 3.8 & 3.6 & 10.7 & 3.7 \\
\hline Mean time of stay in Seville & 2.8 & 3.2 & 10.5 & 3.1 \\
\hline
\end{tabular}

$30.0 \%$ ) and low levels for marihuana and cocaine (in the last 6 months: $3.7 \%$ and $0.5 \%$, respectively). Alcohol consumption, based on the results, varies in function of two fundamental variables, the age group - 25 to 34 years - and sex - man. Consumption in the last month stands out (61.4\%), higher than the $40.1 \%$ in another study involving Latin American immigrants in the community of Valencia(5). The explication for this phenomenon can be due to the fact that, according to the authors of a research about the evolution of immigrant drugs consumption between 2004 and $2008^{(8)}$, this group displays permissiveness and a feeling of dangerousness in legal drugs consumption, mainly of alcohol, contrasting with the perceived high dangerousness of illegal drugs, with lower prevalence levels, in line with this study. These percentages differ in the autochthonous population, with lower levels for alcohol (38.8\%) and other illegal drugs (1.7\%), but not for tobacco $(72.7 \%)^{(5)}$.

In our study, the percentage of high-risk drinkers $(6.8 \%)$ exceeds the $4.8 \%$ described in a research accomplished in an immigrant population of productive age $^{(19)}$. In the last month, the consumption prevalence of this substance amounted to $61.4 \%$ and was higher among men, in the younger group (25 to 34 years) and among people with primary education and less. Perhaps, as affirmed in the abovementioned study of Latin American immigrants ${ }^{(5)}$, they tend to have less information about its effects.
Concerning tobacco consumption prevalence, 30\% of the subjects have consumed 100 cigarettes in life and $26.3 \%$ are current smokers, lower figures than in the study of Latin American immigrants in Valencia(5) about consumption and perceived consumption, where it was affirmed that $31.3 \%$ are habitual smokers. It is significant that the start age of the smoking habit is 17.6 years, similar to the 17.5 years described in the United Nations Workshop against Drugs and Crime for South American countries $^{(18)}$. Both ages are higher than the Spanish average of 13.5 years, according to the report Current Situation of Smoking in Spain (2005-2010)(20).

The prevalence of illegal drugs consumption in our study showed that $5.3 \%$ of the sample are consumers, similar to the $5.7 \%$ in the Valencia study ${ }^{(5)}$. Different risk factors seem to determine these consumption similarities in both studies (ethnic groups of origin, age, parental education, among others), discussed in a study of this population type in the United States ${ }^{(21)}$, which should be taken into account in the development of prevention programs.

Consumption differences were found in function of age. In the group from 25 to 34 years, the risk of having consumed these substances is almost four times higher than in the group over 35 years of age, according to the authors of a study about immigrants in Sweden(22), depending on whether they belong to the first or second generation of immigrants. Over time, an assimilation process happens, through which the drugs consumption 
standards among immigrants change and progressively get closer to those of the citizens in the welcoming country, in line with the North American analysis in the 2000 National Health Study(23). In this framework, the prevalence of marihuana consumption (3.4\%) detected in this study was lower than that of the autochthonous population (24), while cocaine consumption levels have been higher, basically due to Andean immigrants' consumption of this substance, as highlighted in the study that involved a similar population in Valencia(5).

These study results are a source of concern when considering the health problems associated with tobacco, alcohol and illegal drugs consumption and addiction, which produce a greater demand for care and rehabilitation services and require public health policies that aim to solve or at least minimize these problems in society $^{(10)}$. From the Nursing perspective, in the study population, educative interventions are suggested to prevent consumption, in immigrants' health and work contexts, in which nurses have direct and permanent contact with individuals, their families and community, with a view to raising awareness about the consumption problem and enhancing self-care in health ${ }^{(25)}$.

\section{Conclusion}

In this study, which involved a representative sample of the immigrant population in Seville (Spain), the consumption of alcohol, tobacco and illicit drugs is a problem that deserves the attention of health authorities, as it surpasses the prevalence rates in the autochthonous population. Based on the knowledge reviewed in this research report, the health and social entities in Seville will have new elements to intervene, through health promotion and disease prevention activities, prioritizing education on healthy lifestyles. Further research in this sense is pertinent, with a view to providing orientations for the design and implementation of distinguished activities from a nursing perspective, which are adequate to the immigrant group's needs, such as educative activities to prevent smoking, alcoholism and drugs consumption, so as to train this population and, thus, improve immigrants' health level.

\section{References}

1. Dupont H, Kaplan CD, Verbraeck HT, Braam RV, van de Wijngaart GF. Killing time: drug and alcohol problems among asylum seekers in the Netherlands. Int J Drug Policy. 2005;16(1):27-36.

2. Alaniz ML. Migration, acculturation, displacement: migratory workers and "substance abuse". Subst Use Misuse. 2002;37(8-10):1253-7.
3. Buchanan JC, Pillon SC. Uso de drogas entre estudiantes de medicina, tegucigalpa, Honduras. Rev. Latino-Am. Enfermagem. 2008;16(Spec):595-600.

4. Rodríguez-Gazquez MA, Pineda SA, Vélez LF. Características del consumo de tabaco en estudiantes de enfermería de la Universidad de Antioquia (Colombia). Invest Educ Enferm. 2010;28(3):370-83.

5. Tortajada S, Valderrama JC, Castellano M, Llorens $\mathrm{N}$, Agulló V, Herzog B, et al. Consumo de drogas y su percepción por parte de inmigrantes latinoamericanos. Psicothema. 2008;20(3):403-7.

6. Carrasco-Garrido P, De Miguel AG, Barrera VH, JiménezGarcía R. Healthy profiles, lifestyles and use of health resources by the immigrant population resident in Spain. Eur J Public Health. 2007;17(5):503-7.

7. Ojeda V, Patterson TL, Strathdee SA. The influence of perceived risk to health and inmigration-related characteristics on substance use among latins and other inmigrants. Am J Public Health. 2008;98(5):862-8.

8. Tordable I, Sánchez A, Santos S, García MI, Redondo $S$. Evolución del consumo de drogas por inmigrantes entre los años 2004 y 2008. Gac Sanit. 2010;24(3):200-3.

9. Secretaría de Estado de Inmigración y Emigración (ES). Anuario Estadístico de Inmigración en 2008. [acesso 2 nov 2010]. Disponível em: http://extranjeros.mtin.es/es/ InformacionEstadistica/Anuarios/Anuario2008.html

10. Mendes IAC, Luis MAV. Use of psychoactive substances: a new-old challenge. Rev. Latino-Am. Enfermagem. 2004;12(Spec):297-8.

11. Salmeron J, Arillo E, Campuzano J. Tabaquismo en profesionales de la salud del Instituto Mexicano, Morelos. Salud Pub Mexico. 2002;44(1):67-75.

12. Leininger M. Culture care theory: a major contribution to advance transcultural nursing and practices. J Transcultural-Nurs. 2002;13(3):189-92.

13. Centers for Disease Control and Prevention. Surveillance of Certain Health Behaviors Among States and Selected Local Areas. Behavioral Risk Factor Surveillance System, United States. MMWR Surveill Summ. 2010;59(1):1-220. 14. Gaete R, Rodríguez C. Una aproximación al análisis de las cadenas migratorias en España a partir de la Encuesta Nacional de Inmigrantes. Rev Cienc Polít. (Santiago). 2010;30(3):697-721.

15. González JR, Lomas MM, García J, Pascualvaca J, Guardado MJ, Muñoz B, et al. Conductas de salud en inmigrantes latinoamericanos adultos del Distrito Macarena de Sevilla (España). Invest Educ Enferm. 2010;28(3):384-95.

16. Rodríguez-Álvarez E, Lanborena N, Senhaji M, Pereda C, Aguirre $C$. Variables sociodemográficas y estilos de vida como predictores de autovaloración de la salud de los inmigrantes en el País Vasco. Gac Sanit. 2008;22(5):404-12. 
17. Agudelo-Suárez $A E$, Ronda-Pérez $H$, Gil-González D, Vives-Cases C, García AM, García-Benavides F, et al. Proceso migratorio, condiciones laborales y salud en trabajadores inmigrantes en España (proyecto ITSAL). Gac Sanit. 2009;23(Suppl 1): 115-21.

18. Oficina de las Naciones Unidas contra la Droga y el Delito (US). Elementos orientadores para las políticas públicas sobre drogas en la subregión: Primer Estudio Comparativo sobre consumo de drogas y factores asociados en población de 15 a 64 años. [Internet]. Washington: ONUDD; 2008 [acesso 1 jun 2010]. Disponível em: http:// www.cicad.oas.org/oid/NEW/Research/comparativo_ subregional-2008-06.pdf

19. García-Gómez P, Oliva J. Calidad de vida relacionada con la salud en población inmigrante en edad productiva. Gac Sanit. 2009;23(Suppl 1):38-46.

20. Sociedad Española de Neumología y Cirugía Torácica. Situación actual del tabaquismo en España (2005-2010). Prev Tab. 2010;12(Suppl 1):27-33.

21. Delva J, Wallace JM, O'Malley PM, Bachman JG, Johnston LD, Schulenberg JE. The epidemiology of alcohol, marijuana and cocaine use among Mexican American, Puerto Rican, Cuban American, and other Latin American eighth-grade students in the United States: 1991-2002. Am J Public Health. 2005;95(4):696-702.

22. Hjern A, Allebeck P. Alcohol-related disorders in firstand second-generation immigrants in Sweden: A national cohort study. Addiction. 2004;99(2):229-36.

23. Johnson TP, van Geest JB, Cho YI. Migration and substance use: Evidence from the U.S. National Health Interview Survey. Subst Use Misuse. 2002;37(8-10): 941-72.

24. Brugal MT, Barrio G, Royuela L, Bravo MJ, de la Fuente L, Regidor E. Estimación de la mortalidad atribuible al consumo de drogas ilegales en España. Med Clin (Barc). 2004;123(20):775-7.

25. Navarrete RP, Luis MA. Actitud de la enfermera de un complejo hospitalario en relación al paciente alcohólico. Rev. Latino-Am. Enfermagem. 2004;12(Spec):420-6. 